\title{
Viral Oncogene
}

National Cancer Institute

\section{Source}

National Cancer Institute. Viral Oncogene. NCI Thesaurus. Code C19153.

Cancer-causing genes encoded in viral genomes. Usually denoted v-onc. 